Рева Л. В.

доктор філологічних наук, дочент

Ізмайльський державний гуманітарний університет

\title{
ХАРАКТЕРОТВОРЕННЯ В НЕОРЕАЛІСТИЧНИХ НОВЕЛАХ В. ВИННИЧЕНКА
}

У статті запропоновано аналіз двох новел «Роботи!» $i$ «Салдатики!» В. Винниченка. Звернуто увагу на розкриття характерів головних персонажівчоловіків $і$ персонажів-жінок. Через зображення психологічних прочесів внутрішнього буття персонажів та їхні зовнішні вияви зроблена спроба проаналізувати неореалістичну стильову своєрідність автора.

Ключові слова: неореалістичний стиль, характеротворення, характер.

В статье предложен анализ двух новелл «Работь!»» $и$ «Салдатики!» В. Винниченко. Внимание обращено на раскрытие характеров главных персонажей-мужчин и персонажей-женщин. Посредством изображения психологических прочессов внутренней жизни персонажей и их внешних проявлений осуществлена попытка проанализировать неореалистическое стилевое своеобразие автора.

Ключевые слова: неореализм, характеротворение, характер.

The analysis of two short stories "Works!» and «Saldatiki» by V. Vinnichenko. The attention is paid to disclosure of the main men's characters and woman' characters. The attempt to analyse the stylistic originality of the author's neorealism was done through the images of the psychological processes of character's internal life and their external displays.

Key words: noerealism, creation of the character, character.

Поняттєве значення характеру в літературознавстві має досить цікаву історію свого формування, відображеного в загальноприйнятих варіантах, поданих у майже всіх тлумачних словниках. Так, у статті В. Войнова, розміщеній у сучасному Тлумачному словнику української мови (2004), характер визначається як «вдача людини, їі стійкі психічні властивості, особисті риси поведінки і діяльності; твердість волі, наполегливість у досягненні чогось» [ТСУМ 2004]. Саме ці ознаки взяті за основу в наукових працях дослідників, які намагались утвердити термінологічне значення 
характеру в літературознавстві. Гадаємо, що адаптування терміна в критиці мало своїм підгрунтям бажання розширити коло елементів поетичного аналізу. Але наведений вище термінологічний приклад залишається прерогативою енциклопедичних видань, тлумачних словників, словників із психології. У літературознавчих довідниках не прийнято виділяти характер окремо від персонажа. Таким чином, маємо приклад того, що до уваги не береться багатовікова історія утвердження категорії характеру в літературознавстві, адже про фундаментальність цієї категорії в літературі висловлювався ще Арістотель. Проте тенденції сучасного літературного розвитку спрямовані на розкриття характеру в художньому творі. У зв'язку 3 цим особливої складності набуває проблема характеротворення в неореалістичній течії першої третини XX століття, яка в сучасному літературознавстві привертає досить пильну увагу науковців.

Проблема характеру в літературознавстві має багату історію. Свого часу дослідницьку увагу на характер у художньому творі звертали Л. Тимофєєв, В. Фащенко, С. Шаталов та ін. Л. Тимофєєв відповідно до радянських кліше пов'язував характер з історичною обстановкою, із типом людської поведінки, з естетичними поглядами автора, тільки не з психологією людини. У теоретичних обгрунтуваннях дослідників поняття характеру стосується персонажа взагалі, жіночий характер від чоловічого не відокремлюється. В. Фащенко присвятив проблемі характеру в художньому творі кілька десятиліть, залучивши до своїх грунтовних праць знання із суміжних наук, насамперед психології. Категорію характеру він вважав однією з найважливіших, утім визнавав, що в трактуванні поняття «характер» чимало нез'ясованого. 3 цього приводу він писав: «Що иирше - образ чи характер? Входить до нього темперамент чи ні? Може бути персонаж характером? Проте иі питання - другорядні. Істина полягає в тому, щуо головним предметом зображення в літературі є людина. Аспекти ж-чи є вона, людина, лише індивідом, стала чи стає особистістю (зі знаком плюс чи мінус), має "ядро" чи зовсім безхарактерна - то вже за- 
лежить від концептуальності творів, рівня вищої майстерності» [Фащенко 2005: 37-38]. На думку вченого, в аналізі характеру потрібно звертати увагу на соціальні та психологічні концепти художнього відображення, основою яких є мова персонажа, внутрішні монологи, життєві дії, мотивації, вчинки. У літературознавстві В. Фащенко першим розрізнив психологічні типи сутності характеру. Людині в цій класифікації належить перше місце, а далі: індивід, індивідуальність, особистість і каркас особистості. Утім В. Фащенко зазначав, що «людина - істота біосоціальна. Вона може стати особистістю, а може залишитись і на рівні окремого, випадкового індивіда. Все залежить від обставин, від діяльності людини, ї характеру, морального кодексу $i$ - головне від рівня $i$ масштабності їі світогляду» [Фащенко 2005: 43]. Сутності особистості автор книги «Характер і психологізм» надавав принципове значення, він писав, що «людьми народжуються, а особистостями стають» [Фащенко 1988: 23].

Своєрідності набуває характер у художньому відображенні. Так, самі персонажі своєю мовою, внутрішніми монологами і життєвими діями - впевненими чи невпевненими, з добрими намірами чи ні, продуманими чи раптовими - підказують особливості свого типу, до яких входять: сангвінік, меланхолік, флегматик, холерик. Ці типи визначають мотиваційну основу вчинків, які, своєю чергою, створюють фабульний розвиток дії. Особлива складність вивчення характеру полягає в поясненні специфічних рис своєрідністю методу творчості, а ще більше - у зв'язку з належністю до тієї чи тієї естетичної системи, підпорядкованої модерністському спрямуванню, зокрема в межах першої третини XX століття. 3розуміло, що характери персонажів художніх творів, які зумовлені певними доказами належності до літературного напряму, мають відмінні риси. Щодо характеру в неореалістичній українській літературі, то це питання лишається нез'ясованим.

Здебільшого персонаж неореалістичного твору - це не активний діяч або яскрава особистість, а пересічна, невизначна людина. 
Хоча в психологічній палітрі художніх персонажів неореалістичних творів є приклади і досить стійких характерів непересічної людини - особистості. У художньому варіанті таке перевтілення продемонстровано В. Винниченком у новелі «Салдатики!» (1907). Більше того, В. Винниченко - новеліст чи не першим в українській новелістиці створив психологію характеру лідера.

Кут зору авторської уваги зосереджений на Явтухові, якому судилося у відповідальну хвилину стати лідером і, зрештою, загинути. Автор розкриває поступове переродження людини в особливій ситуації: організований гурт села потребує вождя. У нестандартній ситуації з'являється неформальний лідер, той, хто знає, що робити, адже за розгубленою людиною не підуть інші. Тому в новелі повторюються деталі: «...у Явтуха твердий погляд», «тихий, твердо-спокійний голос». До сприйняття крутого повороту в житті героя автор готує читача самим розвитком подій. «Невідомо, ким були підкинені» прокламації, які прочитали всі, а після «село мов прокинулось»: «3 якоюсь дикою ненавистю та злістю закипіли балачки по хатах, з якимсь невідомим досі, гострим болем стали згадувати тепер усі муки і здирства <..> не було вже тої покірливості і боязкого підлизування <..> суворо і похмуро робили вони $<\ldots>$, ніби чогось чекаючи» [Винниченко 2002: 109].

Головний герой Явтух іншого складу людина, іншого характеру. Твердий його погляд виказує власну рішучість і віру, ясні очі чистоту і відкритість намірів. Усе це разом визначає образ іншої людини, яка може мати владу над людьми. Ознайомившись із прокламацією, Явтух «дуже замислився», «тихо він ходив по селу», «щось думаючи» і «дивлячись кудись далеко ясними очима» [Винниченко 2002: 109]. А через три дні він виявив готовність скликати всіх до волості на сход. Такі вольові зусилля пояснюються психологічними можливостями, закладеними біологічно в характері людини. Але про ці речі автор не написав у художньому творі. Тому дослідження такого плану грунтується на з'ясуванні психічних явищ. В. Фащенко вважав, що психічні стани невичерпні й 
плинні і зрозуміти їх можна «тільки завдяки всебічному аналізу, де на першому плані - суспільна поведінка людини, ї̈ невимірні зв'язки зі світом» [Фащенко 2005: 63]. Щодо головного героя новели «Салдатики!» Явтуха, то його вольові зусилля взаємно переплетені й взаємозумовлені емоційними та пізнавальними станами, які є базою шкали трьох основних процесів. А неореалістичні рамки твору пояснюються вимірами емоційного стану героя: «Тихо він ходив по селу, перше мало хто чув від його якоїсь довгої розмови, а тепер ще більше затих, щуось думаючи, твердо склавщи тонкі свої губи» [Винниченко 2002: 109]. Пізнавальний стан виявляється в рядках: «Прочитав раз, прочитав удруге і дуже замислився» [Винниченко 2002: 109]. У Явтуха швидше, ніж у будь-кого, визріли переконання, він глибше збагнув ситуацію і зумів побачити іiі в широкому контексті подій. Характерним $є$ епізод, коли з його ініціативи збирається сільський сход і він сам починає схвильовану промову, в якій апелює до християнської свідомості односельців. Просто й переконливо доводить, що вони самі творять неправду, гріх, бо порушують заповідь: «У поті лиця їж хліб».

Рішучість разом із хвилюванням і певним бажанням повести за собою відтінює «скромність» старости, який «щось бовкнув до селян» і одійшов убік, уступаючи місце Явтухові, що стояв попереду і «мов тільки і чекав», коли йому дадуть слово. Він «голосно і дзвінко почав говорити», а з грудей «виходило довге задержане зітхання». Рефреном його промови став заклик «обкрадають нашу правду». Селяни слухають його «як зачаровані», а він «більше $i$ більше розходився $i$, мов одрубуючи кожне слово, бив ним по сериях» [Винниченко 2002: 109] людей, які хотіли почути про те, що їм кажуть. У словах Явтуха вони знаходять украй важливі для них думки.

Вершиною напруження в новелі стає психологічний двобій, підкріплений словесним і моральним боєм двох особистостейлідерів - Явтуха й офіцера - у кульмінаційній сцені протистояння двох мас - селянської та солдатської. Моральна перевага на боці 
Явтуха, вона передусім у його відвертості й правоті. Взявши відповідальність за долю односельців, він чесно несе іiі аж до своєї смерті. Це визначальні риси його характеру, які підкріплюються взаєминами з людьми. У таких стосунках можна помітити головне: той, хто може повести за собою інших, перестає належати собі. Зазначимо, що для неореалізму характерне збільшення діалогічної частини і зменшення описової. Це пов'язане з домінантою суб'єктивізму, в основі якого психологізм та цікавість до нього. Діалог героїв виконує функцію передачі психологічних процесів. В. Винниченко майстерно передає мовними засобами психологію людини. До речі, на актуалізацію проблеми психологізму в літературознавстві звертав увагу В. Фащенко, на його думку: «психологізм універсальна, родова якість художньої творчості. Його предметом є відображення внутрішньої єдності психологічних прочесів, станів, властивостей $і$ дій, настроїв і поведінки людини» [Фащенко 2005: 49]. У неореалістичній новелі «промінь зору» (за В. Фащенком) зосереджено в погляді оповідача. Оповідач дивиться на минуле з позиції досвідченої людини, тому сюжети багатьох новел мають інший смисл та зміст і не відповідають класичній новелістичній формулі, у поетиці якої застосовуються інтригуючі, захопливі можливості, що випробовує розум і характер героя, але не має істотного впливу на його життя. У новелі В. Винниченка момент людського життя оформлений за всіма законами новелістичного жанру і підтверджуються композиційною структурою твору.

Незважаючи на появу низки публікацій, де розглядаються специфіка авторської естетичної майстерності та критерії художності В. Винниченка, досі залишається не з'ясованою проблема творення характерів не тільки його героїв, а й героїнь. Українська література багата на приклади особистісних характерів жінок. Своєрідні жіночі характери зустрічаємо у П. Куліша, Марка Вовчка, І. Нечуя-Левицького, Панаса Мирного, Б. Грінченка, О. Довженка, Ю. Яновського й ін. Питанням жіночого самовизначення, самооцінки, ставлення до праці і суспільної діяльності присвячено 
новелістичний твір В. Винниченка «Роботи!» (1903). Об’єднує новели «Роботи!» і «Салдатики!» спільна тематика розгортання політичних подій. У житті В. Винниченка також вирувала активна громадсько-політична робота, захоплення і враження від якої позначені знаком оклику в назвах «Роботи!» та «Салдатики!». Здається, що головного героя «Роботи!» Максима автор писав із себе. Двадцятитрирічного письменника і його прообраз об'єднує спільне бажання активних політичних дій (звідси назва, у якій закладено вимогу серйозних справ). Герой вирізняється індивідуалізацією через сприймання Людмилою його вигляду, погляду, стану: «...на його губах <..> грало щось болісне й безнадійне», «...знов якось страшно стало, дивлячись на ией знайомий їй, жалкий $і$ сумний вираз його безпокійних очей $і$ уст» [Винниченко 1989: 145]. Його максималістські промови вражають песимістичністю настрою, у той же час він торкається цілісної системи поглядів з позиції моралі на життя, добро і зло, загальні ідеали: «Не можу жити ... не можу робити... Все паскудно, погано... Всі такі погані... Ну, скажіть, ну, скажіть самі: то добре, щуо вони лаються, щзо вони замість того, щуоб боротися, лаються між собою, сваряться! $<\ldots>$ Хіба так можна?.. ми ж за правду, за все хороше... мені так досадно... Скрізь сварки, скрізь нелюбов... просто всяка віра пропадає у все... I жити не хочеться» [Винниченко 1989: 146]. У словах Максима помітні й риси громадського пафосу, й етикогуманістичний підхід до загальнолюдського і соціального. Тому є підстави для виокремлення своєрідної Винниченкової етичної концепції організації людської спільноти. На жаль, те, що колись хвилювало і вражало автора та подане через монолог Максима, здається, вже стає характерною рисою українського суспільства, приреченого на боротьбу на межі самознищення.

«Захворівши» на страйк, Максим знов шукає роботи. Його романтичні імпульси щодо організації нового страйку зупиняються реалістичними словами Людмили, які відкривають правду про революційний рух, що тримався не тільки на ентузіастах: «...mуm 
треба сотні по двадиять рублів, щуоб зробити те, щзо ви хочете...» [Винниченко 1989: 165]. У тексті відверто подані суїцидальні мотиви, пов'язані з образом героя, його почуттям самотності. Суїцидне бажання Максима повториться у В. Винниченка у 20-х роках у щоденникових записах: «Удруге вже ридав. У дійсності мені краще всього вмерти. Тепер майже спокійний. Так, я вже можу вмерти» [Винниченко 1983: 107]. Від чого це в автора? Чи так позначаються психічна втома і депресивний стан? Але ледь помітне в тексті «тепер майже спокійний» наводить на роздуми: до чого спокійний? До самої думки про можливість своєї смерті? Тоді навіщо про неї думати, тим більше писати? Виникає питання і про зв'язок між психічним станом автора й естетичним річищем його стилістичного спрямування. Адже однією 3 причин виникнення неореалістичної художності є стихійний лад початку XX століття, яке порівняно з XIX ст. має екстремальний характер розвитку подій, що насамперед позначились на творчості митців. І як наслідок, у літературі постають питання психологічного характеру персонажів, як і їх творців.

Слова Максима про смерть - своєрідне відбиття філософських роздумів В. Винниченка щодо соціальних проблем і загального зла. Загалом на характері Максима позначились суперечливі ознаки «гарячого» патріота. У його бажанні щось робити проглядаються не тільки душевні страждання, а й активні наміри самознищення. Тому своєрідно вирішується дилема добра і зла: «Неможливо так жити... Я хочу в тюрму! Я хочу страждать! < .. > Боротись, активно боротись! Мені нудно, я не маю роботи, духовної роботи!.. Я стрілять niдy!» [Винниченко 1989: 148]. Головній героїні Людмилі також притаманне екзистенційне почуття, однак присутнє й бажання жити. Хоча в смутку за Максимом їй «ставало так нудно, так безнадійно, щзо хотілось просто-таки... в тюрму». Описані досить серйозні випробування людської психіки на межі афективного стану, коли зникає поняття моралі, але розкривається проблема вирішення індивідуальних можливостей у суспільному житті. Адже головна 
героїня має характер розсудливої, серйозної та поважної людини. Ї̈̈ інтелігентність, вихованість відбиваються в промовах, настановах, зовнішньому вигляді. Неймовірне перевтілення героїні з «серйозної і строгої» на «дику і страшну» створює особливе сюжетно-фабульне навантаження зі спалахом «моменту істини» в метаморфозі персонажа. Щось подібне у психологічних спостереженнях, але з іншою сюжетною колізією, бачимо в хрестоматійній до недавнього часу новелі М. Коцюбинського «Коні не винні».

3 приводу будови неореалістичної новели В. Винниченка можна процитувати слова В. Фащенка, який писав про композицію новели взагалі: «Ідеалом новелістичної композищії є концентрація уваги на розкритті одного протиріччя, своєрідне зречення від докладного показу багатогранності подій $і$ характерів. Кожний додатковий елемент чи рівнозначний тому, щзо є вже в тексті, відриває від головного $і$ тим самим послаблює безперервність $i$ напругу оповідуваної иілості» [Фащенко 1971: 59]. Ці твердження можна вважати універсальними для тих напрямів, течій і систем, де композиційна структура близька до класичної будови з зав'язкою, розвитком дії, кульмінацією та розв'язкою. На відміну від інших «ізмів», у неореалістичних творах приділяється увага конструкції тексту. Пояснення цього вбачається в поєднанні типового реалізму з пошуковими формами модернізму, проявленими в новелістиці В. Винниченка.

Своїх персонажів В. Винниченко виокремлює 3-поміж маси. Метафори «гурту» створюють базовий фон для показу значення окремої особистості. Свій особистісний потенціал герої розкривають у процесі пошуку істини. Крізь створену автором грань особистості та суспільно складну призму не завжди можна зробити однозначний висновок щодо життєвих позицій персонажів у непростий для вибору історичний час. Вільна людина не виправдовується «обставинами», а приймає повну відповідальність за всі свої дії та їх наслідки. Звідси в героїв неореалістичних творів почуття причетності до всього, що відбувається навколо. 
Письменника більше цікавить поглиблене застосування художньої деталі, звернення до якої служило змалюванню психологічної своєрідності персонажів. Навіть у портретних характеристиках автор заглиблюється в деталізацію внутрішніх порухів душі людини, iї настроїв, переживань. Окремий ситуативний внутрішній стан $€$ результатом певного психічного процесу й поєднує різні відтінки настроїв і почуттів. Безліч чинників формують душевний стан особистості у певний момент. В основі творів - пізнання психіки людини, яка перебуває в пошуку себе самої, намагається усвідомити глибину свого існування і відчути себе часткою буття. Розум героя ніби відтісняється на задній план, а на передній виходять позарозумові аспекти духовного життя персонажів: почуття, інтуїція, уявлення, несвідоме.

Утім, психологічні процеси внутрішнього буття та їхні зовнішні вияви зображуються в конкретних ситуаціях - так яскравіше розкриваються таємниці людини. Зображення начебто «зсередини» літературних персонажів спричиняє художньо-стильову кореляцію: письменник більше звертає увагу на людську психологію, сфери почуттів, роздумів, рефлексій. Останнє створює вже авторські концепції людини та психологічно зумовлений тип іiі характеру в рамках неореалістичної поетики.

\section{БІБЛІОГРАФІЯ}

Винниченко 2002 - Винниченко В. К. Вибране / В. Винниченко. - К. : Школа, 2002. $-304 \mathrm{c}$.

Винниченко 1989 - Винниченко В. К. Краса і сила. - К. : Дніпро, 1989. - 752 с. Винниченко 1983 - Винниченко В. К. Щоденник. - Едмонтон - Нью-Йорк : Канадський інститут Укр. студій Альберт. ун-ту, 1983. - Т. 2. : 1921-1925. - 700 с. ТСУМ 2004 - Тлумачний словник української мови / В. С. Калашник. - 2-ге вид., випр. і доп. - Х. : Прапор, 2004. - 992 с.

Фащенко 1988 - Фащенко В. В. Вибрані статті. - К. : Дніпро, 1988. - 373 с. Фащенко 1971 - Фащенко В. В. Із студій про новелу. Жанрово-стильові питання. К. : Радянський письменник, 1971. - 216 с.

Фащенко 2005 - Фащенко В. В. У глибинах людського буття : Літературознавчі студії. - Одеса : Маяк, 2005. - 640 с. 